\title{
JUDYKATURA A PROCEDURALNE ASPEKTY PRAWA
}

I. Prawo w modelu decyzyjnym może być ujmowane jako wynik generalnych decyzji prawotwórczych albo rezultat decyzji rozstrzygających indywidualne sprawy. Wedle tej idealizacji wyróżnia się dwa dominujące w Europie systemy prawne: kontynentalny oraz common law. Proces konwergencji kultur prawnych sprawia, że stopniowo zaciera się granica między stanowieniem i stosowaniem prawa. Dlatego w krajowym prawoznawstwie coraz więcej dyskutuje się o przejmowaniu przez sędziów odpowiedzialności za treść prawa. Istotne stają się przy tym nie tylko opis i zdiagnozowanie tego zjawiska, lecz także wyposażenie sędziów w wiedzę oraz narzędzia pozwalające pożytecznie oddziaływać na stosunki społeczne.

Temu celowi służą badania prowadzone $\mathrm{w}$ wymiarze wewnętrznym i zewnętrznym prawa. Jest w nich miejsce na badanie rozstrzygnięć doniosłych dla praktyki, podejmowanych przy rozpoznawaniu spraw trudnych i wymagających więcej niż standardowych działań interpretacyjnych, lub innych przejawów aktywności sędziowskiej istotnie oddziałujących na obowiązywanie i stosowanie prawa. W obszar tych zainteresowań wpisuje się badanie stanowiska orzecznictwa wobec przepisów proceduralnych, pomyślane jako przyczynek do ogólniejszej refleksji nad proceduralnymi aspektami sądowego stosowania prawa $^{1}$. Nie ulega bowiem wątpliwości, że co najmniej od kilkunastu lat wzrasta znaczenie czynników gwarancyjnych lub formalnych, wiązanych z szeroko pojmowaną sfera proceduralną prawa. Przyczyniaja się do tego aktywność ustawodawcy, wprowadzającego nowe typy środków ochrony prawnej lub modernizującego zastane instytucje, oraz sędziowie, znacznie częściej niż wcześniej, czyniący zagadnienia kompetencyjne lub formalne centralnym punktem swojej argumentacji.

II. Przeprowadzona analiza dotyczy postępowania cywilnego, karnego oraz sądowoadministracyjnego ${ }^{2}$. Ze względu na rozległość tematu, cele i ramy

\footnotetext{
${ }^{1}$ Wyróżnienie aspektów materialnego i proceduralnego nawiązuje do dogmatycznych ujęć prawa procesowego lub prawa materialnego, lecz nie jest z nimi tożsame z racji przyjętych założeń teoretycznych dotyczących choćby nieprzeciwstawności lub nierozłączności tych aspektów, szerzej na ten temat J. Wróblewski, Materialne i proceduralne aspekty prawa $w$ teorii prawa, ,Studia Prawno-Ekonomiczne”, t. 45,1990 , s. 15 i n.

${ }^{2}$ W rozumieniu źródeł prawa przedmiotem rozważań są: ustawa z 17 listopada 1964 r. - Kodeks postępowania cywilnego (Dz. U. Nr 43, poz. 296 ze zm.; dalej jako: k.p.c.); ustawa z 6 czerwca 1997 r. Kodeks postępowania karnego (Dz. U. Nr 89, poz. 555 ze zm.; dalej jako: k.p.k.) oraz ustawa z 30 sierpnia
} 
Copyright of Journal of Law, Economics and Sociology is the property of Faculty of Law and Administration of Adam Mickiewicz University in Poznan and its content may not be copied or emailed to multiple sites or posted to a listserv without the copyright holder's express written permission. However, users may print, download, or email articles for individual use.

Właścicielem praw autorskich do „Ruchu Prawniczego, Ekonomicznego i Socjologicznego” jest Wydział Prawa i Administracji Uniwersytetu im. Adama Mickiewicza w Poznaniu. Zawartość czasopisma nie może być kopiowana, przesyłana do innych stron internetowych bądź zamieszczana na blogach bez pisemnej zgody wydawcy. Niemniej artykuły można drukować, kopiować lub przesyłać w formie elektronicznej na własny użytek. 
niniejszego szkicu źródłowy materiał empiryczny został ograniczony do wypadków stosowania przez sądy trzech wyróżnionych grup przepisów proceduralnych, mianowicie:

1) przepisów wyznaczających jurysdykcję i właściwość poszczególnych rodzajów sądów,

2) przepisów regulujących postępowanie rozpoznawcze w odniesieniu do prawdy jako celu poznania sądowego,

3) przepisów zawierających normy formalizujące, czyli normy określające warunki, miejsca, sposoby podejmowania czynności procesowych lub inne kwestie związane z organizacja postępowania sądowego ${ }^{3}$.

Przyjęty podział ma charakter typologiczny, zatem nie opiera się na kryteriach zapewniających logiczną lub normatywną rozłączność wyróżnionych grup. Natomiast o ich wyborze zadecydowało przekonanie, że stanowią odrębne, pod względem funkcjonalnym, źródła praktyki interpretacyjnej. Przemawiało za tym kilka argumentów: relewantność zagadnień, skutkująca wyznaczeniem określonego kierunku wykładni przepisów proceduralnych, odwoływanie się przez orzecznictwo do argumentów celowościowych, systemowych lub historycznych, kontrowersje sygnalizowane przez Trybunał Konstytucyjny lub doktrynę oraz znacząca liczba bądź powtarzalność danych wypadków ${ }^{4}$.

Badany materiał stanowią wypowiedzi pochodzące z publikowanych uzasadnień uchwał lub orzeczeń Sądu Najwyższego oraz Naczelnego Sądu Administracyjnego, które $\mathrm{z}$ racji kompetencji ustrojowych, funkcji oraz autorytetu tych organów zostały uznane za reprezentatywne dla praktyki ${ }^{5}$. Zakres czasowy badań wyznaczaja systemowe zmiany procedur sądowych, datujące się od połowy lat dziewięćdziesiątych ubiegłego wieku. Diagnozie poddano przede wszystkim orzecznictwo pochodzące $\mathrm{z}$ ostatnich kilku lat, przyjmując, że jego treść, obejmująca aktualne problemy judykatury, odnotowuje również dorobek wcześniejszy. Zaznaczyć też należy, że przeprowadzona kwalifikacja nie jest kompleksowa ani nie stanowi podstawy do wyczerpującego opisu proceduralizacji sądowego stosowania prawa, pozwala jednak uchwycić pewne tendencje towarzyszące temu zjawisku.

III. Analiza poglądów odnoszących się do stosowania przepisów grupy pierwszej pozwala dostrzec, że cywiliści aprobują i zarazem przyczyniają się do rozszerzenia jurysdykcji sądowej. Poza kompetencją tradycyjnie obejmująca

2002 r. - Prawo o postępowaniu przed sądami administracyjnymi (t.jedn.: Dz. U. 2012, poz. 270 ze zm.; dalej jako: p.p.s.a.).

${ }^{3}$ Szerzej na temat formalizacji S. Czepita, Formalizacja a konwencjonalizacja działań $w$ prawie, w: idem (red.), Konwencjonalne i formalne aspekty prawa, Szczecin 2006, s. 11-12.

${ }^{4} \mathrm{~W}$ artykule przyjęto również założenie, że badane uzasadnienia mają charakter uzasadnień heurystycznych w wersji poznawczej lub argumentacyjnej. Na temat metodologii badań praktyki interpretacyjnej por. O. Bogucki, Wyktadnia funkcjonalna $w$ działalności najwyższych organów władzy sadowniczej, Szczecin 2011, s. 34-41.

${ }^{5}$ Podstawę bazy empirycznej stanowia uchwały oraz orzeczenia tezowane lub publikowane $\mathrm{w}$ piśmiennictwie. W wielu wypadkach sa one powoływane przez komentatorów. Orzeczenia niepublikowane w czasopismach zostały oznaczone numerem Systemu Informacji Prawnej Lex. 
sferę stricte prywatną orzecznictwo uznaje postępowanie cywilne za instytucję służącą realizacji i ochronie również tych roszczeń, wolności lub praw podmiotowych, które nie są dostatecznie chronione przez pozostałe procedury sądowe ani właściwe im środki prawne ${ }^{6}$.

Poszerzenie zakresu kompetencyjnego sądów powszechnych ściśle wiąże się z ewolucją stanowiska orzecznictwa wobec przedmiotu postępowania cywilnego. Wedle poglądu reprezentatywnego do lat dziewięćdziesiątych ubiegłego wieku przy inicjowaniu postępowania obowiązkiem sądu było ustalenie tzw. rzeczywistego (materialnego) przedmiotu procesu ${ }^{7}$. Po transformacji zapatrywanie to poddano zdecydowanej krytyce i ostatecznie przyjęto, że prawo do sądu przysługuje jednostce niezależnie od tego, czy podmioty pozostające w konkretnym sporze są rzeczywiście związane stosunkiem materialnoprawny, czy też żaden stosunek prawny ich nie łączy. Ewolucja poglądów judykatury cywilnej wskazuje więc na wzrost znaczenia funkcji gwarancyjnych, motywowany realizacja zasad sprawiedliwości proceduralnej ${ }^{8}$.

$\mathrm{Z}$ perspektywy ustrojowej odrębności sądownictwa administracyjnego operującego kryterium legalności przy kontroli działania administracji stosowanie przepisów kompetencyjnych rysuje się nieco inaczej. W orzecznictwie dominują poglądy, że podstawowym wyznacznikiem kompetencji sądu administracyjnego powinno być kryterium materialnoprawne, jednakże jego brak nie w każdym wypadku skutkuje niedopuszczalnością rozpoznania sprawy ${ }^{9}$. Przy rozważaniu jurysdykcji coraz istotniejsze stają się bowiem argumenty oparte na katalogu zasad sprawiedliwości proceduralnej oraz wzgląd na możliwość realizacji ochrony prawnej w innym postępowaniu sądowym ${ }^{10}$. Poglądy optujące za niedopuszczalnością kontroli sądowej w wypadku braku innego trybu ochrony należą już do rzadkości ${ }^{11}$. Szerokie pojmowanie gwarancji proceduralnych prowadzi niekiedy do kumulacji środków ochrony prawnej przez przyjęcie właściwości różnych systemowo sądów w sprawach o tożsamej kwalifikacji

${ }^{6}$ Dominujące stanowisko reprezentuje uchwała 7 sędziów SN z 27 czerwca 2007 r., III CZP 152/06, OSNC 2007, nr 12, poz. 175; por. również uchwały SN z 21 grudnia 2006 r., III CZP 131/06, OSNC 2007, nr 10, poz. 152; 5 kwietnia 2006 r., III CZP 121/05, OSNC 2006, nr 11, poz. 178; 4 czerwca 2004 r., III CZP 27/04, OSNC 2005, nr 7-8, poz. 119; 23 lutego 2005 r., III CZP 85/04, OSNC 2006, nr 1, poz. 4; 18 listopada 2009 r., II PZP 7/09, OSNP 2010, nr 7-8, poz. 82.

7 Zob. uchwałę 7 sędziów SN z 20 kwietnia 1970 r., III CZP 4/70, OSNC 1970, nr 9, poz. 146.

${ }^{8}$ Por. postanowienia SN z 22 kwietnia 1998 r., I CKN 1000/97, OSNC 1999, nr 1, poz. 6; 10 marca 1999 r., II CKN 340/98, OSNC 1999, nr 9, poz. 161 oraz 8 marca 2001 r., III KKO 5/2000, OSNP 2002, nr 5, poz. 128. Zob. również J. Gudowski, Wptyw Konstytucji i orzecznictwa Trybunału Konstytucyjnego na pojęcie dopuszczalności drogi sqdowej, w: T. Ereciński, K. Weitz (red.), Orzecznictwo Trybunału Konstytucyjnego a Kodeks postepowania cywilnego, Warszawa 2010, s. 418-428.

9 Tendencję tę wykazuja przypadki wykładni przepisu art. $3 \S 2$ pkt 6 p.p.s.a. zawierającego zwrot „,sprawa z zakresu administracji publicznej” (art. $3 \S 2$ pkt 5 lub pkt 6 p.p.s.a.), zob. uchwały NSA z 1 czerwca 1998 r., OPS 3/98, ONSA 1998, nr 4, poz. 109; 6 września 2000 r., OPS 11/00, ONSA 2001, nr 2, poz. 52; 21 lipca 2008 r., I OPS 4/08, ONSAiWSA 2008, nr 6, poz. 90 oraz wyroki 7 sędziów NSA z 17 maja 1999 r., OSA 1/99, ONSA 1999, 4, poz. 109 i 6 listopada 2000 r., OSA 2/00, ONSA 2001, nr 2, poz. 48.

${ }^{10}$ Uchwały NSA z 27 lipca 2000 r., FPS 12/99, ONSA 2001, nr 1, poz. 7; 29 marca 2006 r., II GPS 1/06, OSP 2006, nr 11, poz. 122; 1 marca 2010 r., II FPS 9/09, OSP 2010, nr 12, poz. 122; 5 grudnia 2011 r., I OPS 2/11, Lex, nr 1052438 i 5 grudnia 2011 r., I OPS 3/11, Lex, nr 1089623.

${ }^{11}$ Uchwała NSA z 23 lutego 2010 r., II GPS 6/09, ZNSA 2010, nr 3, s. 120 i n. 
materialnoprawnej ${ }^{12}$ lub jej wyodrębniania tylko ze względu na szczególne instytucje proceduralne ${ }^{13}$.

Rozszerzenie zakresu kognicji karnej spowodowane było, podobnie jak w pozostałych procedurach, zmianami stanu prawnego i wyznaczeniem sądom nowych zadań i ustaleniem nowych kompetencji. Dyskusja w tej mierze koncentruje się wokół przepisów proceduralnych zawierających wyraźne odesłania kompetencyjne. Przegląd powoływanych argumentów wskazuje na trwałość i stabilność funkcjonowania podstawowych instytucji tej dziedziny prawa oraz stosowanego aparatu pojęciowego. Z racji szczególnego charakteru odpowiedzialności prawnokarnej wypadki stosowania wykładni rozszerzającej w zakresie kompetencyjnym są nieliczne i służą przede wszystkim zagwarantowaniu odpowiedniego standardu ochrony jednostki w postępowaniach, do których posiłkowo stosuje się przepisy karne ${ }^{14}$.

IV. W obrębie przepisów grupy drugiej za interesujące należy uznać wypowiedzi podejmujące problem prawdy $\mathrm{w}$ danym postępowaniu sądowym. $\mathrm{Z}$ deklaracji ujawnianych w pisemnych motywach orzeczeń wynika, że judykatura opowiada się za korespondencyjnym pojmowaniem prawdy. To ujęcie odpowiada zresztą intuicjom prawników i utrwalonemu w prawoznawstwie sposobowi rozumienia podstawy faktycznej decyzji sądowego stosowania prawa $^{15}$. Prawda w dogmatyce postrzegana jest przez pryzmat zasady ${ }^{16}$ wyznaczającej cel poznania sądowego lub metody bądź środków, za pomoca których są ustalane i wyjaśniane zjawiska albo stany rzeczy o konsekwencjach prawnych. Z tych względów orzecznictwo podejmuje problem prawdziwości $\mathrm{w}$ odniesieniu do przepisów proceduralnych rządzących postępowaniem dowodowym. Osią tej relacji jest opozycja dwóch naczelnych pojęć paradygmatu epistemologicznego prawa procesowego: „prawda obiektywna” (zwana też „,prawdą materialna”) oraz „prawda sądowa” (nazywana czasami „,prawda formalną”, wokół których toczy się dyskusja na temat słuszności określonego

\footnotetext{
${ }^{12}$ W uchwale NSA z 4 lutego 2008 r. (I OPS 3/07, OSP 2008, nr 7-8, poz. 89) opowiedziano się za poglądem, że skierowane do organu żądanie zwrotu bezprawnie pobranej opłaty za wydanie karty pojazdu jest sprawą administracyjną, którą organ załatwia w drodze aktu lub czynności, na które przysługuje skarga do sądu administracyjnego. Natomiast w uchwale z 16 maja 2007 r. (III CZP 35/07, OSNC 2008, nr 7-8, poz. 72) SN uznał, że dopuszczalna jest droga sądowa do dochodzenia roszczenia o zapłatę, którego podstawę stanowi nienależne pobranie opłaty za wydanie karty pojazdu. Stanowisko to zostało potwierdzone w uchwale SN z 6 czerwca 2012 r. (III CZP 24/12, OSNC 2013, nr 1, poz. 5).

${ }^{13}$ Interesującym przykładem jest stanowisko dotyczące stosowania sankcji określonej w przepisie art. $55 \S 1$ p.p.s.a.; por. postanowienie NSA z 5 lipca 2006 r., II OSK 1024/06, ONSAiWSA 2006, nr 6, poz. 156 oraz postanowienie WSA w Gdańsku z 19 listopada 2007 r., II SO/Gd 5/07, ONSAiWSA 2009, nr 4, poz. 69.

${ }^{14}$ Uchwały SN z 16 listopada 2006 r., SNO 69/06, Lex, nr 470208; 8 lutego 2000 r., I KZP 51/99, OSNK 2000, nr 3-4, poz. 30 oraz wyrok SN z 12 września 2006 r., SNO 41/06, Lex, nr 470193.

15 Szerzej O. Bogucki, Teoretyczne aspekty zasady prawdy materialnej $w$ nowym modelu postepowania cywilnego, „Ruch Prawniczy, Ekonomiczny i Socjologiczny” 2000, z. 1, s. 53 i n.

${ }^{16}$ Syntetycznie na temat pojmowania zasad prawa w krajowym prawoznawstwie M. Zieliński, Zasady $i$ wartości konstytucyjne, w: A. Bałaban, P. Mijal (red.), Zasady naczelne Konstytucji RP z 2 kwietnia 1997 roku. Materiaty 52. Ogólnopolskiego Zjazdu Katedr Prawa Konstytucyjnego w Międzyzdrojach (27-29 maja 2010 r.), Szczecin 2011, s. 21-40.
} 
modelu postępowania rozpoznawczego oraz trafności zastosowanych $\mathrm{w}$ nim instrumentów poznawania prawdy.

Sędziowie cywiliści - najbardziej krytyczni wobec doktryny, która wykształciła i utrwaliła pojęcie prawdy obiektywnej - nie kwestionuja potrzeby zagwarantowania korespondencji rezultatów poznania sądowego. Wskazują wręcz, że wprowadzone korekty wyposażyły procedurę cywilną w skuteczniejsze narzędzia odkrywania prawdy ${ }^{17}$. Podkreślają jednak, że to właśnie strony zainteresowane pozytywnym dla nich rozstrzygnięciem czynią to efektywniej niż inkwizycyjnie działający organ. Dlatego obowiązkiem sądu jest przede wszystkim dbałość o to, by reguły poznawcze zostały w równy i sprawiedliwy sposób zrealizowane $\mathrm{w}$ procesie ${ }^{18}$. Z tych też względów akceptują słuszność pozostawienia w Kodeksie postępowania cywilnego kompetencji śledczych służących ochronie strony słabszej ${ }^{19}$.

Oprócz utrwalonego w procedurach szczególnych lub odrębnych przyzwolenia na ograniczenie dążenia do ustalenia prawdy ze względu na ochronę innych, nie mniej istotnych dóbr lub wartości ${ }^{20}$, pojawiają się głosy zrównujące pozycję zasady prawdy $\mathrm{w}$ procesie sądowym $\mathrm{z}$ regułami prakseologicznymi, służącymi przyśpieszeniu lub usprawnieniu postępowania cywilnego, wynikające z negatywnej oceny dotychczasowej efektywności stosowania prawa oraz zmian normatywnych dokonywanych w celu jej poprawy. Tym też należy tłumaczyć intensywność wykorzystywania rozmaitych rygorów formalnych lub prekluzji dowodowych, redukujących materiał dowodowy i modyfikujących klasyczny model postępowania rozpoznawczego opartego na idei ,,prawdy obiektywnej”21.

Ustrojowa odrębność oraz specyfika modelu kontroli sfery publicznej sprawiają, że sędziowie administracyjni nie są tak mocno jak cywiliści uwikłani $\mathrm{w}$ problemy epistemologiczne procedury administracyjnej. Tę relację oddaje stosunek orzecznictwa do ,,prawdy obiektywnej”, która bez większych zastrzeżeń uznawana jest za zasadę wyznaczającą cel postępowania dowodowego ${ }^{22}$.

${ }^{17}$ Chodzi przede wszystkim o zmiany treści przepisów art. 3, 5, 212, 213 § 1, 229, 232 zd. 2 oraz 339 $\S 2$ k.p.c.

${ }^{18}$ Uchwała 7 sędziów SN z 19 maja 2000 r., III CZP 4/2000, OSNC 2000, nr 11, poz. 195; uchwała SN z 17 lutego 2004 r., III CZP 115/03, OSNC 2005, nr 5, poz. 77 oraz wyroki SN z 22 lutego 2006 r., III CK 341/05, OSNC 2006, nr 10, poz. 174; 4 stycznia 2007 r., V CSK 377/06, OSP 2008, nr 1, poz. 8 i 30 I 2009 , II CSK 440/2008, Lex, nr 527122.

${ }^{19}$ Wyroki SN z 22 lutego 2006 r., III CK 341/05, OSNC 2006, nr 10, poz. 174 oraz 23 października 2007 r., III CSK 108/2007, Lex, nr 358857.

${ }^{20}$ Dotyczy to przykładowo domniemań prawnych uregulowanych w przepisach art. $62 \S 1$ lub $\S 2$ Kodeksu rodzinnego i opiekuńczego.

${ }^{21}$ Zob. powołaną w przypisie 18 uchwałę SN z 17 lutego 2004 r., III CZP 115/03 oraz uchwały SN z 4 czerwca 2004 r., III CZP 28/04, OSNC 2005, nr 4, poz. 63; 17 czerwca 2005 r., III CZP 26/05, OSNC 2006, nr 4, poz. 63 i wyrok SN z 19 stycznia 2005 r., I CK 410/04, OSNC 2006, nr 1, poz. 7.

${ }^{22}$ Uchwała pełnego składu NSA z 26 października 2009 r., I OPS 10/09, ZNSA 2009, nr 6, s. 94 i n.; uchwały NSA z 22 lutego 2007 r., II GPS 2/06, ZNSA 2007, nr 3, s. 87 i n.; 9 marca 2009 r., I FPS 4/08, ONSAiWSA 2009, nr 3, poz. 47; 27 kwietnia 2009 r., II FPS 1/09, ONSAiWSA 2009, nr 5, poz. 88 ; 20 maja 2010 r., OPS 13/09, ONSAiWSA 2010, nr 5, poz. 82; 11 października 2011 r., I FPS 1/10, ONSAiWSA 2011, nr 1, poz. 4; 13 października 2011 r., II GPS 1/11, Lex, nr 951321; wyrok SN z 23 listopada 1994 r., III ARN 55/94, OSNAPiUS 1995, nr 7, poz. 83 oraz wyroki NSA z 2 lutego 1996 r., II SA 2875/95, „Wokanda” 1996, nr 6, s. 32 i n.; 26 października 2005 r., I FSK 188/05, Lex, nr 173261; 17 stycznia 2006 r., I FSK 511/05, Lex, nr 187601 i 31 stycznia 2007 r., II FSK 199/06, „Przegląd Orzecznictwa 
Brak też sygnałów o potrzebie zmiany takiego paradygmatu. Przypuszczać można, że jego akceptacji sprzyjają: wyeliminowanie obowiązku rekonstrukcji stanu faktycznego, ograniczenie kompetencji śledczych sądu, odrębność trybu i przesłanek, wedle których dokonywana jest sądowa kontrola działania administracji, oraz satysfakcjonująca sprawność postępowań sądowych.

Jednakże i w tej dziedzinie występują sytuacje zmuszające sędziów do rozwiązywania kolizji zachodzących między „obiektywistycznie” pojmowaną prawda a partykularnymi regułami proceduralnymi. Do wypadków rewizji tradycyjnego modelu poznawczego można bowiem zaliczyć sprawy związane z ustalaniem stanu ksiag podatkowych ${ }^{23}$, faktur ${ }^{24}$ oraz kwestie stosowania reguł ciężaru dowodzenia $\mathrm{w}$ sprawach dotyczących nieujawnionych źródeł przychodów, podatku od towarów i usług, podatku akcyzowego bądź zwolnień lub ulg podatkowych ${ }^{25}$.

Orzecznictwo sądów karnych w kwestii prawdy nie wykazuje tak istotnego przewartościowania, jakie dokonało się $\mathrm{w}$ dziedzinie cywilnej. Imperatyw poszukiwania prawdy jako celu poznania w procesie karnym nie jest kwestionowany, w rozważaniach zaś nad pozostałymi zasadami procesowymi zaznacza się ich instrumentalny i zarazem funkcjonalny stosunek do zasady ,,prawdy materialnej”26. Związek między przepisami prawa dowodowego a tą zasadą jest najmocniej eksponowany w obrębie dyskusji na temat kasacji. Treść przepisu $\S 2$ art. 2 k.p.k. stanowiącego, że podstawą wszystkich rozstrzygnięć powinny być prawdziwe ustalenia faktyczne, jest interpretowana jako „ogólna dyrektywa postępowania”, „,deklaracja ustawodawcy stanowiąca swoiste zobowiazanie co do ukształtowania procesu karnego w taki sposób, by realizował zasadę prawdy materialnej”, albo „zasada ogólna określająca cele postępowania karnego", której normatywność statuuje jednak powiązanie z innymi - szczegółowymi przepisami Kodeksu ${ }^{27}$.

Podatkowego" 2008, nr 1, poz. 6. Część judykatury operuje jednak zamiennie terminem „prawda materialna”, por. wyroki NSA z 16 listopada 2004 r., FSK 908/04, Lex, nr 147835; 19 kwietnia 2005 r., FSK 955/04, Lex, nr 799402; 7 czerwca 2005 r., FSK 2509/04, Lex, nr 173225; 26 października 2005 r., I FSK 188/05, Lex, nr 173261; 25 listopada 2005 r., FSK 2702/04, Lex, nr 799007; 14 grudnia 2005 r., I FSK 186/05, Lex, nr 195825; 17 stycznia 2006 r., I FSK 511/05, Lex, nr 187601; 19 grudnia 2006 r., II FSK 84/06, Lex, nr 283911; 5 stycznia 2007 r., II FSK 86/06, Lex, nr 286675; 15 stycznia 2013 r. oraz uchwała NSA z 11 października 2010 r., I FPS 1/10, ONSAiWSA 2011, nr 1, poz. 4.

${ }^{23}$ Wyroki NSA z 21 października 2008 r., I FSK 1189/07, Lex, nr 496275 i 12 maja 2011 r., I FSK 837/10, Lex, nr 1080670.

${ }^{24}$ Wyroki NSA z 19 grudnia 2000 r., III SA 1715/99, Lex, nr 46516; 26 października 2005 r., I FSK 188/05, Lex, nr 173261; 14 grudnia 2005 r., I FSK 186/05, Lex, nr 195825; 20 maja 2009 r., I FSK 380/08, Lex, nr 593951 i 9 stycznia 2007 r., I FSK 347/06, Lex, nr 284343.

${ }^{25}$ Szeroko wraz z wyborem orzecznictwa A. Hanusz, Podstawa faktyczna rozstrzygnięcia podatkowego, Kraków 2006, s. 194-220; D. Strzelec, Obowiazek wyjaśnienia stanu faktycznego w postepowaniu podatkowym - watpliwości praktyczne i teoretyczne, „Palestra” 2011, nr 3-4, s. 86-100.

${ }^{26}$ Zob. wyroki SN z 28 marca 2008 r., III KK 484/2007, ,Prokuratura i Prawo” 2008, nr 9 (wkł.), poz. 10; 10 lutego 2010 r., V KK 264/2009, OSNK 2010, nr 1, poz. 277.

${ }^{27}$ Postanowienia SN z 16 marca 2001 r., V KKN 19/99, Lex, nr 51668; 21 grudnia 2001 r., III KKN 443/98, Lex, nr 52010; 11 kwietnia 2006 r., V KK 360/2005, OSNK 2006, nr 1, poz. 819; 8 maja 2006 r., V KK 362/2005, Lex, nr 186966; 19 października 2006 r., V KK 254/2006, Lex, nr 198109; 16 stycznia 2007 r., V KK 345/2006, OSNK 2007, nr 1, poz. 161 i 13 grudnia 2012 r., IV KK 326/12, Lex, nr 1243089 oraz wyrok SN z 10 sierpnia 2006 r., III KK 457/05, OSNK 2006, nr 1, poz. 1553. Krytycznie w kwestii wskazanego związania O. Bogucki, M. Zieliński, Zasada bezstronności - art. 4 k.p.k. a podstawy środka odwotawczego, „Palestra” 2009, nr 11-12, s. 91-92. 
Problem prawdziwości ustaleń faktycznych jest najczęściej podejmowany w kontekście wadliwego albo niewadliwego przebiegu lub wyników postępowania dowodowego. Wskazuje się tu również, choć zdecydowanie słabiej w skutkach niż w orzecznictwie sądów cywilnych, na aspekty pragmatyczne ${ }^{28}$. Jednakże współczesne orzecznictwo, opowiadając się nadal za materialnym (korespondencyjnym) ukierunkowaniem postępowania rozpoznawczego, coraz silniej akcentuje związek prawdy ze standardami sprawiedliwości proceduralnej, wyznaczającymi warunki rzetelnego procesu ${ }^{29}$.

V. Inne spostrzeżenia przynosi badanie stosowania norm formalizujących, wynikajacych $\mathrm{z}$ przepisów proceduralnych zaliczonych do grupy trzeciej. Szczególnie interesujących przykładów dostarcza przegląd stanowisk wobec przepisów nakładających obowiązek posługiwania się formularzami urzędowymi. Wprowadzenie do trybów szczególnych procedury cywilnej obowiązku stosowania gotowych blankietów służyć miało rozszerzeniu dostępu do sądu, m.in. przez ułatwienie jednostkom dopasowania indywidualnego żądania ochrony do określonego trybu procesowego. Równie istotne było usprawnienie postępowania sądowego. Zastosowane rozwiązania, w szczególności wynikające $\mathrm{z}$ przepisów wykonawczych, już $\mathrm{w}$ pierwszych miesiącach obowiązywania spotkały się z zarzutem nadmiernej restryktywności powodującej ograniczenie prawa dostępu do sądu. Jednakże sędziowie, być może usatysfakcjonowani poprawą wyników statystycznych osiąganych za ich pomocą, dość długo nie sygnalizowali swoich wątpliwości aksjologicznych ${ }^{30}$.

Podobnie przedstawia się historia stosowania rygorów formalnych, wynikających z przepisów proceduralnych, dotyczących przedsiębiorców lub innych podmiotów niereprezentowanych przez profesjonalnych pełnomocników ${ }^{31}$. Dopiero powszechna krytyka, a przede wszystkim ingerencja Trybunału Konstytucyjnego sprawiły, że orzecznictwo nie deklaruje już tak silnego poparcia dla rygorystycznego formalizmu procesowego ${ }^{32}$.

Kolejna ilustracja omawianego zjawiska jest stanowisko orzecznictwa cywilnego wobec skargi kasacyjnej. Zastosowanie surowych wymogów przy jej sporządzaniu i wnoszeniu uzasadniane było publicznymi funkcjami,

${ }^{28}$ Wyrok SN z 28 marca 2008 r., III KK 484/07, Lex, nr 370249 oraz postanowienie SN z 18 grudnia 2008 r., V KK 267/08, Lex, nr 485030.

${ }^{29}$ Zob. uchwała składu 3 sędziów SN z 26 września 2002 r., I KZP 23/02, OSNKW 2002, nr 11-12, poz. 98 oraz wyroki SN z 23 września 2004 r., II KK 132/04, Lex, nr 126695 i 23 czerwca 2010 r., III KK 265/09, Lex, nr 598843.

${ }^{30}$ Por. uchwały SN z 30 maja 2001 r., III CZP 19/2001, OSNC 2001, nr 12, poz. 170; 14 grudnia 2001 r., III CZP 67/01, „Prokuratura i Prawo” 2002, nr 6 (wkł.), poz. 38 oraz 17 stycznia 2002 r., III CZP 78/2001, „Monitor Prawniczy” 2002, nr 4, s. 147 i n.

${ }^{31}$ Zob. wyroki TK z 20 grudnia 2007 r., P 39/06, OTK 2007, nr 11, poz. 161 oraz z 26 czerwca 2008 r., SK 20/07, OTK 2008, nr 5, poz. 86. Dalszych przykładów dostarcza lektura wyroków TK z 13 stycznia 2004 r., SK 10/03, OTK 2004, nr 1, poz. 2; 2 października 2006 r., SK 34/06, OTK 2006, nr 9, poz. 118; 1 kwietnia 2008 r., SK 77/06, OTK 2008, nr 3, poz. 39 oraz 26 czerwca 2008 r., SK 20/07, OTK 2008, nr 5, poz. 86.

${ }^{32}$ Por. postanowienia SN z 25 listopada 2007 r., II PZ 44/07, OSNP 2009, nr 1-2, poz. 13 ; 16 kwietnia 2008 r., V CZ 17/08, OSNC-ZD 2009, nr 1, poz. 8; 29 stycznia 2008 r., II PZ 68/07, OSNP 2009, 7-8, poz. 100; 11 marca 2009 r., II PZ 47/08, Lex, nr 489013. 
nadzwyczajnym charakterem oraz przymusem adwokackim ${ }^{33}$. Odwołując się do tych racji, judykatura cywilna wypracowała pojęcie wymogów konstrukcyjnych, a więc takiej klasy braków formalnych, których sanacja uznawana jest za niedopuszczalną ${ }^{34}$. Po okresie pewnej stabilizacji poglądów pojawiły się jednak różnice dotyczące granic formalizmu procesowego i potrzeby łagodzenia jego niepożądanych konsekwencji ${ }^{35}$.

Inaczej na tym tle prezentuje się orzecznictwo sądów administracyjnych. Wynikać to może z zalet modelu kontrolnego oraz częstszego niż w wypowiedziach sądów powszechnych (cywilnych) powoływania się na systemowe cele ochrony sądowej. Właśnie za pomoca argumentów funkcjonalnych, niekiedy nawet wykładni rozszerzającej, łagodzone sa negatywne dla stron skutki formalizacji ${ }^{36}$. Krytykowane sa natomiast wypadki formalizmu restryktywnego ${ }^{37}$.

Wnioski takie uzasadnia również dyskusja dotycząca podstaw skargi kasacyjnej. Poważne rozbieżności co do interpretacji przepisów art. 174 p.p.s.a doprowadziły do podjęcia uchwały przez pełny skład Naczelnego Sądu Administracyjnego ${ }^{38}$. Teza uchwały i przedstawiona w niej argumentacja wskazują na rozluźnienie wymogów konstrukcyjnych tego środka zaskarżenia i w konsekwencji służą merytorycznemu rozpoznawaniu spraw przez sąd drugiej instancji ${ }^{39}$.

${ }^{33}$ Szeroko wraz z wyborem orzecznictwa SN zob. T. Zembrzuski, Skarga kasacyjna. Dostępność w postępowaniu cywilnym, Warszawa 2009, s. 254 i n.

${ }^{34}$ Orzecznictwo SN w tym zakresie jest obszerne. Przykładowo można tu wskazać wyroki z 4 kwietnia 1997 r., II CKN 68/97, Lex, nr 50793; 7 kwietnia 1997 r., III CKN 29/97, OSNC 1997, nr 6-7, poz. 96; 17 stycznia 1997 r., I PKN 62/96, OSNP 1997, nr 17, poz. 313; 22 sierpnia 2000 r., IV CKN 1181/00, OSNC 2001, nr 1, poz. 19; 26 września 2000 r., IV CKN 1518/00, OSNC 2001, nr 3, poz. 39 oraz postanowienia z 21 marca 2000 r., II CKN 711/00, OSNC 2000, nr 7-8, poz. 151; 12 października 2007 r., V CSK 309/07, OSNC-ZD 2008, nr 3, poz. 81; 13 października 2005 r., II PZ 39/05, OSNP 2006, nr 17-18, poz. 274 i 17 maja 2006 r., II PZ 17/06, OSNP 2007, nr 9-10, poz. 136.

${ }^{35}$ Różnicę podejścia w kwestii stopnia formalizacji skargi kasacyjnej obrazuje dyskusja dotycząca stosowania art. 380 k.p.c. Według poglądu dominującego podstawą kontroli sądu kasacyjnego może być tylko wyraźnie sformułowany wniosek; por. postanowienia SN z 3 marca 2005 r., II CZ 197/04, Lex, nr 177247; 17 lipca 2008 r., II CZ 54/08, Lex, nr 447663; 23 listopada 2011 r., IV CZ 99/11, Lex, nr 1102548. Według drugiego wystarczające jest ujawnienie woli rozpoznania niezaskarżalnego orzeczenia, bez potrzeby wyraźnego powołania w skardze kasacyjnej art. 380 k.p.c.; por. postanowienia SN z 19 maja 2004 r., I CK 37/04, OSNC 2005, nr 5, poz. 90; 19 grudnia 2006 r., V CZ 105/06, Lex, nr 610107 oraz wyrok SN z 24 czerwca 2009 r., I CSK 535/08, Lex, nr 518133.

${ }^{36}$ Reprezentatywnym przykładem jest rozróżnianie przez judykaturę pojęć braku formalnego „istotnego” oraz braku formalnego „nieistotnego”. Do „,nieistotnych” zaliczane są np. braki dotyczące odpisów lub uwierzytelnienia pism procesowych. Ich wystąpienie nie jest uznawane za przeszkodę do nadania sprawie dalszego biegu; por. postanowienie NSA z 27 czerwca 2008 r., I OZ 430/08, Lex, nr 493811 i wyrok NSA z 23 listopada 2005 r., I OSK 133/05, Lex, nr 196679. Zob. również postanowienia NSA z 26 listopada 2008 r., I OSK 1401/08, Lex, nr 466382; 18 stycznia 2011 r., I OSK 2120/10, Lex, nr 687104; 18 maja 2010 r., I OZ 316/10, Lex, nr 672958 oraz 21 grudnia 2011 r., II FZ 447/11, Lex, nr 1096194.

${ }^{37} \mathrm{Na}$ uwagę zasługuje postanowienie NSA z 25 stycznia 2008 r., II FZ 646/07, OSP 2008, nr 7-8, poz. 86, dotyczące zakresu uzupełnienia wymogów formalnych przez stronę, której przywrócono termin do wniesienia środka zaskarżenia uprzednio odrzuconego. Zob. również krytykowaną w tym orzeczeniu uchwałę 7 sędziów SN z 31 maja 2000 r., III ZP 1/00, OSNC 2001, nr 1, poz. 1.

${ }^{38}$ Uchwała z 26 października 2009 r., I OPS 10/09, ZNSA 2009, nr 6, s. 94 i n. Zob. również wyrok TK z 20 września 2006 r., SK 63/05, OTK 2006, 8, poz. 108 oraz postanowienie TK z 19 października 2010 r., SK 8/09, OTK 2010, nr 8, poz. 94.

39 Swiadczy o tym liberalne stanowisko NSA w kwestii powoływania w podstawach skargi kasacyjnej 
W procedurze karnej formalizm, którego zastosowanie motywowane jest względami gwarancyjnymi, dotyczy przede wszystkim należytych standardów działania sądu oraz oskarżyciela. Natomiast w stosunku do oskarżonego lub jego obrońcy normy formalizujące są stosowane w sposób mniej surowy, gdyż w orzecznictwie sądów karnych dominuje stanowisko, że negatywne konsekwencje rygorów proceduralnych nie moga godzić w podstawowe prawa oskarżonego ${ }^{40}$. W podobny sposób, zatem zdecydowanie inaczej, niż czynią to judykatura cywilna lub administracyjna, ocenia się skutki procesowe zaniedbań profesjonalnego pełnomocnika (obrońcy) ${ }^{41}$. Na korzyść przysługujących stronie gwarancji orzecznictwo karne rozwiązuje też kolizje między ,statyczną" kazuistyką przepisów formalizujących a problemami, jakie stwarza rozwój nowoczesnych środków komunikacji ${ }^{42}$. Normy formalizujące nie pełnią przy tym tak istotnej funkcji $\mathrm{w}$ dyscyplinowaniu stron i przyśpieszaniu postępowania, jak w dziedzinie cywilnej, jakkolwiek ze względu na potrzebę usprawnienia procesu karnego i projektowane w tym celu zmiany w niedalekiej przyszłości należy oczekiwać zwiększenia stopnia formalizacji postępowania przygotowawczego oraz sądowego.

VI. Podsumowując wnioski płynące $\mathrm{z}$ analizy materiału przyporządkowanego wszystkim wyróżnionym problemom badawczym, należy stwierdzić, że w orzecznictwie sądów dostrzegalna jest tendencja do poszerzania zakresu jurysdykcji ze względu na standardy sprawiedliwości proceduralnej. Szczególnie aktywna jest tu judykatura cywilna, uznająca tę drogę sądową za elastyczny i zarazem uniwersalny środek ochrony prawnej. Wiąże się to ściśle ze zwrotem w kierunku proceduralnego wyznacznika kompetencji. Kryterium to stosowane jest również $\mathrm{w}$ celu przeciwdziałania negatywnym sporom kompetencyjnym. W efekcie tych działań łatwiejsze stały się dostęp do wymiaru sprawiedliwości oraz zainicjowanie sporu sądowego. Spowodowało to znaczące zwiększenie obciążenia sądów i problemy z techniczną organizacją postępowań rozpoznawczych lub wykonawczych.

Problemy te pojawiają się również w orzecznictwie sądów administracyjnych, choć jego analiza dostarcza nieco innych wniosków. Kompetencja sądów administracyjnych jest również systematycznie poszerzana, ale przy jej ustalaniu sędziowie operują kryterium właściwości szczególnej, opartym przede wszystkim, lecz już nie wyłącznie, na stosunku materialnoprawnym. Podobnie jak w dziedzinie cywilnej uwaga sądownictwa administracyjnego nakierowana

przepisów ustrojowych, por. W. Piątek: Podstawy skargi kasacyjnej $w$ postępowaniu sqdowoadministracyjnym, Warszawa 2011, s.180-181 i powołane tam orzecznictwo.

${ }^{40}$ Por. wyroki SN z 19 kwietnia 2011 r., II KK 285/2010, „Prokuratura i Prawo” 2011, nr 10 (wkł.), poz. 17; 20 lipca 2011 r., V KK 167/11, OSNK 2011, nr 9, poz. 85; 14 lutego 2001 r., V KKN 395/98, Lex, nr 52027; 1 października 2003 r., IV KK 292/03, Lex, nr 82324 oraz postanowienie SN z 22 kwietnia 2010 r., IV KZ 20/10, OSNK 2010, nr 1, poz. 892.

${ }^{41}$ Postanowienia SN z 10 stycznia 2000 r., IV KKN 32/99, „Prokuratura i Prawo” 2000, nr 5 (wkł.), poz. 5; 3 października 2001 r., V KKN 81/00, Lex, nr 51921; 16 lutego 2006 r., V KK 480/05, OSNK 2006, nr 1, poz. 377; 9 lipca 1996 r., IV KZ 32/96, OSNK 1996, nr 9-10, poz. 60 oraz 30 sierpnia 1999 r., III KZ 74/99, OSNK 1999, nr 9-10, poz. 57.

${ }^{42}$ Zob. uchwałę SN z 20 grudnia 2006 r., I KZP 29/2006, OSNK 2007, nr 1, poz. 1, dotycząca skuteczności wniesienia środka odwoławczego za pomocą telefaksu. 
jest na poszukiwanie pozytywnych rozwiązań kolizji kompetencyjnych. Brak natomiast wyraźnych sygnałów o zakłóceniach funkcjonalności procedury sądowej ${ }^{43}$.

Orzecznictwo sądów karnych odnoszące się do kwestii właściwości cechuje powściągliwość w rozszerzaniu kompetencji, uzasadniana funkcjami i celami postępowania karnego. Argumenty aksjologiczne przemawiające na rzecz rozszerzenia jurysdykcji pojawiaja się $\mathrm{w}$ sprawach dotyczących postępowań, w których procedura karna jest wykorzystywana posiłkowo, aby wzmocnić gwarancje proceduralne oskarżonego albo obwinionego.

Zawarte $\mathrm{w}$ analizowanych orzeczeniach wypowiedzi, odnoszące się do modelu poznawczego ukształtowanego przez normy zaliczone do grupy drugiej, wskazuja na zdominowanie dyskursu prawniczego przez zagadnienia proceduralne. Problem prawdziwości lub korespondencyjności poznania rozważa się najczęściej w kontekście reguł dowodowych wynikających z przepisów proceduralnych i zasad procesowych. Przyczyn konstytuowania formuł prawdy, symbolizowanych opozycja ,,prawda obiektywna” - ,prawda sądowa”, należy zatem upatrywać w postępującej relatywizacji metod jej poznawania w poszczególnych dyscyplinach prawa procesowego, powodowanej przez coraz liczniejsze i różniące się treściowo przepisy proceduralne ${ }^{44}$. Istota i przyczyny tej proceduralnej konwencjonalizacji prawdy nie są roztrząsane przez judykaturę, chociaż ich obecność sygnalizuje dyskusja dotycząca inkwizycyjnego albo kontradyktoryjnego modelu ukształtowania postępowania dowodowego i stosowania odpowiadajacych tym modelom instytucji i reguł proceduralnych na gruncie danych dziedzin prawa materialnego. W tej też pragmatycznej i lokalnej (instytucjonalnej) perspektywie sędziowie operuja zasada prawdy.

W wypowiedziach judykatury na temat prawdy rzadko pojawiaja się odwołania do pozanormatywnych wzorców poznania, jeśli zaś występuja - to dotyczą zastosowania reguł logiki lub doświadczenia życiowego przy dokonywaniu ustaleń faktycznych. Nieczęsto spotkać można przejawy aprobaty albo dezaprobaty dla przepisów prawa dowodowego ze względu na ich aksjologiczne usprawiedliwienie. Na podstawie tych obserwacji przypuszczać można, że sędziowie deklarują zaufanie do instrumentów oferowanych przez prawo stanowione i akceptuja paradygmaty poznawcze stosowanych regulacji procesowych. Warto jednak zwrócić uwagę, że postawa taka dotyczy przede wszystkim przepisów opartych na dyrektywach funkcjonujących w naukach empirycznych lub tych, które choć swoiste dla prawa, można uznać za utrwalone i ustabilizowane. Natomiast kontrowersje pojawiają się najczęściej przy stosowaniu przepisów nowych, wprowadzanych przede wszystkim z myślą o uzyskaniu satysfakcjonującej szybkości lub sprawności danego postępowania sądowego.

W odniesieniu do wszystkich badanych procedur, także w dziedzinie karnej, zauważalny jest odwrót od paternalistycznego, inkwizycyjnego trybu ochrony w kierunku rozwiązań charakterystycznych dla ustawodawstwa należytych

\footnotetext{
${ }^{43}$ Ze względu na rosnącą liczbę skarg kasacyjnych pojawiła się jednak potrzeba zapewnienia należytej prawności postępowania przed NSA.

${ }_{44}$ Zob. M. Zieliński, Poznanie sqdowe a poznanie naukowe, Poznań 1979, s. 195-197; również T. Gizbert-Studnicki, Prawda sadowa w postępowaniu cywilnym, „Państwo i Prawo” 2009, z. 7, s. 5 i n.
} 
gwarancji ${ }^{45}$. Jak można sądzić, krajowi sędziowie akcentują w ten sposób potrzebę proceduralnego zabezpieczenia prawa do rzetelnego procesu przez wyznaczenie sędziemu pozycji bezstronnego arbitra, niepodejmującego ex officio działań śledczych w celu wyjaśnienia tła danego sporu sądowego. W wielu jednak wypadkach nadal opowiadają się za potrzebą pozostawienia instrumentów służących korekcie kontrowersyjnych wypadków działania reguł ciężaru dowodu oraz wyrównywaniu szans strony słabszej.

Stosunek judykatury do przepisów formalizujących jest zróżnicowany i niejednoznaczny. Z jednej strony sędziowie akceptuja sens formalizacji: uznają ja za immanentny składnik procedury, konieczny do realizacji jej zasadniczych celów, zapewnienia niezbędnej efektywności, sprawności, adekwatności do postępu technologicznego, a także czynnik dyscyplinujący i edukujący strony. Z drugiej strony daje się zauważyć nadmierna skłonność wykorzystywania przepisów proceduralnych do ograniczania materialnej sfery poznania. Przy stosowaniu norm formalizujących widoczna jest również presja powodowana przez kłopoty z wydolnością postępowań sądowych, ciążąca zwłaszcza na cywilistyce.

VII. Zarysowane problemy dowodzą stopnia trudności i złożoności przenikania się materialnych i proceduralnych aspektów sądowego stosowania prawa. Podążanie za standardami sprawiedliwości formalnej i obejmowanie ochroną prawną coraz większego obszaru życia społecznego powoduje istotne zwiększenia obciążenia sądów i co za tym idzie - problemy z efektywnością rozstrzygania sporów. Konieczne staje się opanowanie rosnącej liczby spraw oraz poszukiwanie narzędzi pozwalających na efektywne i skuteczne oddzielenie i rozpoznanie wypadków rzeczywistej (zobiektywizowanej) oraz deklarowanej (subiektywnej) potrzeby udzielenia ochrony sądowej.

Ustawodawca usiłuje temu przeciwdziałać za pomoca kazuistycznych regulacji proceduralnych. Ze względu na ich ilość, niespójność lub kolizje z zasadami systemu prawa lub zasadami procesowymi sędziowie coraz częściej odwołują się do rezultatów wykładni funkcjonalnej. Przegląd argumentów powoływanych w cytowanych orzeczeniach uświadamia zarazem, jak dokonywane wybory zależą od preferowanego systemu wartości, wiedzy, zaangażowania oraz wielu innych czynników składających się na aktywny albo pasywny stosunek sędziów do kultury.

Z kolei w dyskursie dotyczącym norm formalizujących można zaobserwować zjawiska niepokojące, wskazujące na nadmierne skupienie judykatury na zagadnieniach organizacyjnych, co - przy narastającej intensywności tego procesu - grozi zdominowaniem praktyki sądowego stosowania prawa przez różnego typu dyrektywy celowościowe lub normy techniczne, mniej istotne bądź drugorzędne $\mathrm{z}$ punktu widzenia aksjologicznych założeń oraz celów prawa procesowego. Również analiza orzecznictwa w tym właśnie obszarze ujawnia najwięcej przykładów postaw biernych lub legitymistycznych, choć spotkać w nim można również wypadki aktywizmu służącego pozytywnemu rozwiązywaniu konfliktów komunikacyjnych.

${ }^{45}$ Szerzej na ten temat zob. L. Morawski, Argumentacje, racjonalność prawa $i$ postępowanie dowodowe, Toruń 1988, s. 162-167. 
Przedstawione symptomy nie wyczerpują oczywiście tytułowego zagadnienia ani nie pozwalaja na postawienie jednoznacznej diagnozy stanu funkcjonowania sprzężeń między materialnymi a proceduralnymi aspektami sądowego stosowania prawa. Sygnalizują natomiast konieczność zintensyfikowania i zunifikowania badań w tym przedmiocie oraz uświadamiania sędziom potrzeby refleksji nad skutkami proceduralizacji prawa, za które w coraz większym stopniu stają się odpowiedzialni ${ }^{46}$. Realizacji tych zadań sprzyjać będzie z pewnością uczynienie zarysowanych problemów polem współpracy praktyki oraz ogólnych i szczegółowych nauk prawnych.

\author{
dr Jacek Jaśkiewicz \\ jtjaskiewicz@hotmail.com
}

\title{
JUDGES AND THE PROCEDURAL ASPECTS OF LAW
}

\section{Summary}

The purpose of this paper is to discuss the role that judges may play in the field of procedural law. The considerations are based on opinions delivered by judges of the Supreme Court and the Supreme Administrative Court and presented in published reasons for resolutions or decisions of these courts. The analysis covered, predominantly, judicial decisions contained in the last recent court annuals in the presumption that previous solutions and judgments are relevant and apply to current problems of procedural law application. The results of the research suggest an increased role of judges in procedural law, whose jurisdiction widens and leads, in consequence, to greater repetitiveness of procedures. However, the very effectiveness and efficiency of recognising cases continues to pose difficulties, the result of which is that judicial discourse remains dominated by organisational or technical problems. These are due to still inadequate legislation on the one hand, and judges' fixed attitudes to procedural issues, on the other. The maintenance of legitimised behaviour and lack of axiological involvement on the part of judges are conducive to creating communications barriers, which in turn is detrimental to the material functions and purposes of court protection.

${ }^{46}$ Szczególnie potrzebne jest wskazywanie sędziom niebezpieczeństw wynikających z uprawiania technicznego modelu racjonalności. Na ten temat por. M. Zirk-Sadowski, Uniwersalna pragmatyka a teoria i filozofia prawa, ,Studia Prawno-Ekonomiczne”, t. 37, 1986, s. 36-39. 